\title{
Africa: \\ Understanding and Managing Violent Conflicts
}

\author{
Taiwo Oladeji ADEFISOYE \\ Oluwaseun BAMIDELE
}

\begin{abstract}
In 2011, the World Bank reported that an estimated 1.5 billion people worldwide live in conflict-affected countries where repeated cycles of political and organized violence hinder development, reduce human security and result in massive humanitarian suffering. Out of this figure, the African continent is host to a significant number. Since the 1960s, the continent has been laden with varied dimensions of conflicts, orchestrated by, but not limited to, border disputes, communal/ethnic differences and political agitations caused by her colonial origin and other internal trajectories. Using document analysis conducted through systematic review, this work identifies causes and consequences of conflicts in Africa and prospects for peaceful and enduring conflict resolution mechanism. It was also identified that the response of African Union and other sub-regional organizations to the intense and chronic nature of conflict situations in the region has, over the years, ranged from apathy to reliance on short-term security measures, which has otherwise not able to proffer lasting solutions to the conflict situations. It was posited that rather than rely on heavy military operations and response-centric approaches to conflict management, there is a dire need for a robust effort at good governance and people-centred policy reforms where socioeconomic development is accorded high priority to mitigate the perception

Taiwo Oladeji ADEFISOYE

Department of Political Science,

Ekiti State University,

E-mail: taiwo.adefisoye@gmail.com

of alienation and marginalization among various groups in African countries. Besides, appropriate institutional responses by African states are critical and necessary to transforming the volatile environment to peaceful havens, conducive for development and progress.
\end{abstract}

Oluwaseun BAMIDELE

Institute of Peace, Security and Governance,

Ekiti State University

E-mail: oluwaseun.bamidele@gmail.com

Conflict Studies Quarterly

Issue 22, January 2018, pp. 3-17

DOI:10.24193/csq.22.1

Published First Online: 01/10/2018
Keywords: Africa, Violent conflicts, peaceful resolution, good governance.

\section{Introduction}

In Africa, the security landscape has become increasingly volatile and complex as a result of different actors involved. An examination 
of the incidences of violence during this period reveals a multiplicity of conventional and unconventional armed conflict actors. These comprise state and non-state actors acting both domestically and trans-nationally. Furthermore, varying patterns of violence in different regions in Africa are observed, both of high and low intensity, alongside an unprecedented number of casualties. In some cases, the results are long-standing unresolved issues while in others, new sources of armed conflict have emerged to compound existing ones, exacerbating the scope and magnitude of violence. Across Africa, the various types of organized economic, social, religious, ethnic and political violence include, but are not limited to, terrorism, secessionist insurgency, inter- and intra-faith violence, sectarian strife and ethnic turf wars.

The strategic nexus and close coordination between various groups perpetuating the violence often makes it difficult to draw a distinction between the typology of violence and the motivations guiding the groups' behavior. The response of African Union and of other sub-regional organizations to the intense and chronic nature of these incidents has over the years ranged from apathy to reliance on short-term security measures. As rightly observed by Kofi Annan, these measures have included heavy-handed military operations to alleged extra-judicial killings, enforced disappearances involving the police and intelligence agencies and external military intervention since the 1960s, with the state's tacit consent (Annan, 1998). Efforts to meaningfully address underlying social, economic, religious, ethnic and political conditions contributing to the fragile environment in the African region have been negligible.

Africa's recent experience with extreme, high-intensity levels of violence has been reported in a number of prominent empirical studies. The Global Peace Index (GPI) 2014 identifies Africa as one of the regions that qualifies to be in the category of "war" having crossed the unfortunate figure of one thousand battle-related deaths in a year's time (GPI, 2014). The GPI 2014 positions Africa amongst the three least peaceful regions in the world. It suggests that, since the 1980s, Africa has been ranked as showing the fastest decline in peacefulness regionally and globally (Annan, 2001). Africa ranked first out of six regions in the $2014 \mathrm{GPI}$ and remained first for the year 2015. The report further noted that Africa was among the worst performers in the world in terms of the number of armed conflicts fought (GPI, 2014).

This article critically examines the various manifestations of protracted violent conflicts in Africa and offers a contextual description of conflict dynamics. It examines the region generally. The article does not, however, address organized political or extremist violence in Africa. Although the African region experiences protracted violent conflicts, one of the items on the agenda of the African Union, and has been a perpetual battleground for a number of armed non-state actors mentioned in this article, the issue is beyond the scope of this study due to its predominant intra- and inter-state nature. 


\section{Conflict Categories in the African Region}

Observably, violent conflicts in Africa and in most of the other parts too, can be broadly put in four categories, namely (i) those imposed and escalated by the global political, strategic and developmental dynamics, including the role of great powers, (ii) those inherited and strategically induced in inter-state engagements, (iii) those precipitated and nurtured by the internal political turbulence, socio-cultural fault-lines and developmental distortions and (iv) those that are caused and covered by the non-state actors. The first category includes violent conflicts inflicted by the forces and factors from outside the region. For example, conflict generated in or between the African countries as a result of the Cold War politics. The Cold War politics had impinged on Africa to deepen and sharpen various regional divides and complicate internal and inter-state violent conflicts. While the strategic imperatives of the world order dynamics have directly contributed to Africa's violent conflicts, the global developmental and ideological issues have done so indirectly and gradually by stimulating and reinforcing many internal violent conflicts, for example Libya. Globalization as a process, for instance, has, besides its many positive and creative dimensions, a negative fallout as well and that has added to Africa's woes and worries (Viggo, 2002). In the second category, violent conflicts would assume an important place. In the third category would fall all the insurgencies and ethnic/sectarian conflicts in Africa and the fourth category would cover the activities of the terrorist groups, like the attacks on Somalia, Nigeria, Mali, Chad, Cameroon, Kenya, etc., or the operations of the insurgent and criminal groups across the borders in West and North African regions.

The violent conflicts included in these categories could be those that manifest diplomatic tensions, strong disagreements and non-violent popular protests. Both violent and non-violent conflicts have a tendency to feed into each other and get transformed into each other. The science and art of violent conflict management also focus on transforming violent conflicts into non-violent conflicts and preventing the non-violent conflicts from assuming violent dimensions. Non-violent inter-state conflicts in the African region have been triggered by territorial disputes, disagreements on access to or sharing of resources like water, energy, fisheries as well as by disputes and disagreements on issues related to trade, transit and investments, migration of people across the borders, etc. The fourth category of violent conflicts, related to the operations of non-state actors, has, in recent years, attracted so much attention, particularly after the Cold War, as the nature of conflict on the continent evolved, moving away from the prevalence of border related inter-state violent conflicts to the proliferation of governance-related intra-state violent conflicts-across African borders with or without support from any established state. Underlining the importance of non-state actors in conflict studies, African Union Chairman Mr. Idriss Deby Itno, President of the Republic of Chad, said in his address to the General Assembly Meeting held in Addis Ababa in 
30th January 2016:

Today, there is a fundamental change in the nature of violent conflicts, which is not just evolving from one stage to another, but is undergoing change as a result of shift in the character of the violent conflicts. The age of global interdependence has ensured the decline in violent conflicts between African states. Nevertheless, there is escalation in the violent conflicts involving non-state actors, particularly when the lines between state and non-state actors are considerably becoming vague... The cocktail of NGOs, social media and the like, as spotted in Africa, induce kinetic and physical consequences ultimately culminating in regime changes. In addition, the technology has also empowered the non-state actors to pose an important challenge to the state. The obliteration of distinction between state and non-state actors along with the punctured boundaries of state sovereignty has created new situations demanding novel perspectives (AfricaNews.com, 2016).

The categories of violent conflicts identified above are analytical and therefore, the violent conflicts thus generated do not necessarily remain confined to any single category in their practical and real-life manifestations. More often, it is the spill-over of one category of violent conflict into the other one that makes real-life violent conflicts complex and intricate for the states and the analysts to address. This was amply demonstrated in the Ethiopia-Eritrea war that led to the emergence of a sovereign independent Eritrea. This inter-state violent conflict was generated by the internal turbulence in Ethiopia, by the military regime's authoritarian and ruthless way of dealing with the demands of the Eritrea people of then East Africa. There are many more instances of internal violent conflicts spilling over into a neighbouring country to precipitate inter-state conflict in Africa.

The categories of violent conflicts in Africa listed above also are not represented in any chronological or hierarchical order. There is a general assumption globally, and for good reasons, that inter-state violent conflicts have increasingly given way to violent conflicts within the states (Harvey, 1995). Africa is no exception to this but the boundaries of violent conflicts should be seen as porous and not rigid in Africa and elsewhere. The trends in violent conflict types are not unilineal either. There is even a possibility that another Ethiopia-Eritrea war or even an open DR Congo conflict facing a two-front war situation would emerge (Adeyemo, 2000). Some of the most intractable and protracted internal violent conflicts in Africa, like the Boko Haram insurgency in Nigeria, Lord's Resistance Army (LRA) in Uganda, ethnic challenges in Rwanda/Burundi and the Tuareg insurgency in Mali, have been brought to an end in rather unexpected ways.

However, bringing violent conflicts to an end does not mean that they have been resolved and that their root causes have been fully addressed and eliminated. In Uganda, even after the end of the war, political resolution of the ethnic issue is awaited and the 
promise of building a new Uganda, that brought Yoweri Museveni into the mainstream of national politics, remains to be fulfilled and institutionalized, though militarism and authoritarianism have been removed and a republican political order has been established. Similarly, in Mali, the Tuareg revolt has been a reoccurring in the country's history without any possible hope of permanent resolution. Cases of farmer-herders' conflicts in Nigeria, which have assumed varied dimensions in time past, have been addressed with a kid-glove which has only produced a fragile or momentary peace without any sign or assurance of a permanent truce between warring parties.

\section{Africa's Violent Conflicts:}

\section{Regional and International Pressures}

Although this article focuses primarily on Africa's violent conflicts, the region's overall security situation is also shaped, both directly and indirectly, by relations with its neighbours and the role of the external actors in the international community. It is therefore important to acknowledge this outer layer of complexity and the key external players influencing security dynamics within the African region. Studying armed conflicts in Africa is a big intellectual enterprise. In today's Africa, identifying and managing hotspots is not simply a matter of pulling out a map, spotting the wildfires and empowering diplomats to douse the flames.

To understand today's major violent conflicts and confrontations, one must recognize the various ways in which Africa's economic, social, religious, ethnic and political conditions enable them. Violent conflicts are much more likely to arise or persist when those with the means to prevent or end them will not do so (Adedeji, 1999). One may even go further than this to say that violent conflicts will persist until the political and ethnic leaders of the region and the African power system that they create, perpetuate and manage, stop precipitating or fuelling them for their strategic interests. In violent conflict studies, the questions of resource-related conflicts, power-related conflicts and human security concerns (neglected until the end of the last millennium), are gradually being taken on board but the effort and resources allocated to them are not at adequate levels yet.

Africa has earned a status of its own as an important area of focus in violent conflict studies and why wouldn't it? After all, it is a continent which has witnessed many full-scale inter- and intra-state violent conflicts, where adversaries were armed. The Armed Conflict Database produced by the Institute of Security Studies (South Africa) has been identifying many African regional violent conflicts. A large number of African region think-tanks, including those funded by governments as well as those affiliated to established universities, are involved in violent conflict studies, with two of them based in South Africa - the Institute of Security Studies and ACCORD - running a many program on the study of "Armed Conflicts in African Region" for the past ten years 
(Eminue, 2004). The Institute of Security Studies and ACCORD have been computing information on violent conflicts in Africa on a periodic basis (Otite, 1999). This paper proposes to identify the violent conflict types in African region and discuss their causes and consequences.

\section{Causes of Violent Conflicts in African States}

Two major roots of Africa's violent conflicts have been their colonial legacies and turbulent processes of post-independence nation- and state-building. Three sets of colonial legacies having considerable violent conflict potential were: (i) the creation of unnatural and absurd state systems, (ii) unresolved boundaries of these states and (iii) undefined status of diversity of its ethnic and religious minorities and social groups. The end of colonial rule in Africa came as a result of a combination of wars of independence and peaceful struggles waged by African leaders. The success of these struggles ensured 'decolonisation' of African countries. However, the partition of Africa created unnatural and absurd states of Africa as many-piece entities, in all regions of Africa, separated by a huge amount of territory and boundary problems. This absurdity is still yet to be rectified years after the partitioning and so many have been resolved after fierce violent conflicts. The British colonial interests converged here with the emerging US interests that shaped the contours of the Cold War in strategically dividing the whole Africa.

The communal basis of the region of Africa, however, kept African states uncertain of their national identity and created a potentially volatile and almost perennial cause of communal violent conflicts in all the regions. The absurdity of the methods used for transfer of power was also inherent in the application of the principle of seat-tight syndrome. Not only did this principle make the task of building and consolidating new states in Africa difficult and prone to violent conflicts, but also contributed to the persisting source of tensions and wars between them, such as on the Burundi case (Adebayo) and most recently the case of Gambia. The colonial mind-set to keep African region divided was evident in many other forms as well.

The colonial legacy of unresolved borders also continues to keep Africa relations prone to violent conflicts. Two of the longest imperial boundaries of French colonies left unsettled were with Mali/Burkina Faso and Ethiopia/Eritrea. While the former is a major contentious issue, the latter resulted in a war between Ethiopia/Eritrea in 1952 and continues to be vulnerable to another violent conflict. The two countries signed a boundary agreement and the complicated question of enclaves of one country in the territory of another was resolved. However, both these agreements remain to be ratified by the parties or actors owing to internal political pressures. Between the late 1950 s and the late 1990s, more than half of Africa's states were involved in some form of boundary-related conflict. William Zartman have explained that while some of these conflicts were resolved speedily through bilateral negotiations or third-party facilitation 
(Côte d'Ivoire-Liberia, 1960/1961; Mali-Mauritania, 1960/1963 and Dahomey-BissauNiger, 1963/1965), others were very protracted, e.g. Ethiopia-Somalia (1950 to 1978 and beyond) and Cameroon-Nigeria (1963 to 2002) (Zartman, 2013). In the case of Somalia and Ethiopia, the boundary issue gets complicated by the changing course of Somali-inhabited Haud and Ogaden regions of Ethiopia.

It was mentioned earlier that the violent conflicts of Africa resulted from sources located outside the region, in the global political and strategic order. The more-than-a-decadelong "war on global terrorism" that has engulfed many of the African countries like Somalia, Nigeria, Niger, Cameroon, Tunisia, Libya, Kenya, etc. directly and indirectly resulted from the Western intervention in the African region. However, there was something more in terror attacks than just an act of terrorism. To say that terrorism was a collateral damage may amount to stretching the argument a bit too far, but one must objectively assess that the attacks on African states were carefully planned against the region politically, militarily and economically. The targets were not African people but the icons of Western power and dominance which African terrorist groups have been resenting and preparing to challenge.

However, the end-game in African countries and its consequences for violent conflicts in African region remains to be seen and they promise to be hugely challenging to Africa's peace, stability and long-term security. This is however not the first time that an extraregional power's intervention or an imperative of the global political dynamics has resulted in violent conflicts in Africa. Historically and contemporarily, the DR Congo is one of the most troubled nations in Africa. Right from and after its independence from Belgian colonization, the DR Congo has been in perpetual conflict. As far back as the early sixties, the DR Congo was caught in the web of Cold War politics and thus, became the first country in Africa to witness the UN peacekeeping intervention in Africa.

Since the demise of the Cold War politics, the story of DR Congo has hardly changed. The country is yet to know peace. While many authors and scholars have written extensively on the volatility and violence that have characterized DR Congo, more especially on the poor resources governance syndrome, few of these scholars have proffered effective pathways to ensuring peace this resource-rich country. That conflict is still the costliest violent conflict to this day.

The above instances underline the important role that the Cold War prevailing global strategic system played in imposing violent conflicts on African countries. The Cold War politics had also widened and sharpened the entire African region: the case in the Great Lakes region, West Africa and the Horn of Africa divide, and made the African violent conflicts intractable. The strategic aspects of the world order have directly contributed to the violent conflicts in Africa, but its ideological and developmental aspects have created conditions that have encouraged, intensified and sustained violent conflicts in African societies. Globalisation, which has otherwise stirred up the global developmen- 
tal processes and opened up several opportunities for the countries of Africa, has also induced distortions by widening inequalities, creating and sustaining poverty, enhancing consumerism, encouraging crony capitalism and intensifying cultural alienation. These distortions in the development processes have generated conditions for violent conflicts identified by the Institute of Security Studies and ACCORD Conflict Analysis Framework (Laitin, 2007). Globalisation has unleashed three explosions in the African region, namely of information, of identity and of aspirations. Political systems have not been able to cope with the imperatives of these explosions in the face of severe governance and leadership deficits. A telling example of governance deficit can be seen in the failure of the African regimes not only in leaving large social constituencies and marginalised sections ungoverned and un/under-developed but also in not rehabilitating large numbers of African people uprooted as a result of mega developmental projects like high dams, mining and deforestation.

Numerous examples of leadership failure in Africa in the recent years are evident in the failure of institutionalising democratic gains in Burundi, Libya, Central African Republic, Somalia or Uganda and thus the creation of potential for violent conflicts. In Rwanda, even years after the defeat of the mass killing, the ruling regime has failed to find credible answers to the root causes of the ethnic violent conflict. Excessive preoccupation with personal and group (party) power has been a strong reason behind the leadership failures in such cases. Struggles for power and influence at various levels in African polities have sustained and vitiated raging violent conflicts. Remember the political use of Tutsi in Rwanda, Hausa in Nigeria, as some of the typical examples in this respect.

Africa's violent conflicts are also rooted in its turbulent and unfinished processes of state- and nation-building. Unsettled social equations and political hierarchies sharpen ethnic and sectarian violent conflicts. Identity and ownership of the state- and the nation-in-the-making bring diverse social groups at daggers drawn. The unsettled national identity of some African states accentuated by the dominance of Tutsi over the Hutu and Twa social groups and South Sudan's decision in 2011 to carve itself out as an independent state by ignoring the sensitivities of the minority groups of Africanism and Arabism has been at the root of serious internal violent conflicts in these countries. In Central African Republic, the past 30-plus years of democratic evolution had to confront numerous challenges of integrating the marginalised social groups and now the surge of hitherto neglected and discriminated caste and tribal groups are putting huge pressure on the capacities of the state and its political processes. Unequal distribution of the fruits of development and the widening gap between aspirations and acquisitions of the social groups also fuel violent conflicts. In Angola, Zimbabwe, Namibia, Uganda, Burundi and Rwanda, the years of insurgency were sustained by the marginalised tribal and regional groups that are now demanding equal and respectable status, which has in turn paralysed the process of constitution-drafting and institution-building. 
Africa's unnatural and open borders along with its contiguous ethnic and social spread have easily allowed one region's internal violent conflicts to spill over into the other, leading to bilateral violent conflicts. Such spill-overs have been spurred by conscious decisions of one country to employ and exploit the internal violent conflicts of its neighbouring country in pursuance of its strategic, foreign or domestic policy interests. Most of the African countries are guilty of exploiting their neighbour's predicament in this respect at one time or another. Uganda's involvement in Rwanda's ethnic conflict and the emergence of Burundi, Somalia's cross-border terrorism against Kenya and Ethiopia, Somalia's resentment over the flow of Somali refugees from Garrisa (Kenya) are well known examples of internal violent conflicts turning into bilateral and regional violent conflicts in Africa. Some of these transformed violent conflicts have also been resolved by a radical shift in the policies of the aggravating state towards the violent conflictaffected state(s) and forging cooperation to deal with the spill-over(s).

\section{Consequences of Africa's violent conflicts}

The consequences of Africa's violent conflicts are evident in the structure of its states as well as in the societies that constitute these states. We noted earlier that violent conflicts were fuelled largely by the way African states were structured after the colonial rule and these inherent violent conflicts also restructured the states of Africa. Three examples stand out in this respect. One is the obvious question of Southern Africa (Zimbabwe, Namibia, South Africa, etc.), Western Africa (Nigeria, Mali, Cameroon, etc.) and Central Africa (Central African Republic, DR Congo, Sudan, South Sudan, etc.), which has, at least temporarily, altered the boundaries of the regions. It is not possible to say, at this stage, what the eventual solution of the Africa problem would be. The question of redefining and restructuring the structures of African states as a result of its violent conflicts remains relevant.

The Western or foreign military interventions have resolved many African violent conflicts, but if the ethnic question is not resolved militarily, politically and amicably, the re-emergence of separatist tendencies in future cannot be ruled out. In Mali, the persisting violent conflicts in northern region have the viruses of separatism, though it can be hoped that Mali's resilient polity would not let these issues explode. In South Sudan, if minority groups are not integrated through a federal structure and socio-economic accommodation, it is feared by Southern Sudanese that a separatist demand would gain momentum.

There is, however, no support for minorities' separatism in South Sudan. African states are also afflicted by the separatist sentiments which are facing insurgency. Somalia's frontier province facing Somaliland continues to have strong separatist sentiments based on unresolved national identity. There is a serious debate among analysts and policy makers whether Somalia would be able to keep its unity and territorial integrity 
intact in the face of multiple internal violent conflicts and religious and sectarian extremism, divided polity, economic and developmental dilemma, and isolation from allies (Obi, 2012). The uncertainty in Somalia particularly after the state has been declared a failed state may result in a violent redefining of the Somaliland state as espoused by a number of analysts (Zounmenoun \& Okeke, 2012).

In addition to creating new states and altering state boundaries, violent conflicts in Africa have also changed regimes and political systems. In Uganda, violent conflict was a driving force behind the 1967 constitution, when Obote abrogated the independence constitution and introduced the republican constitution (commonly referred to as the 'pigeon-hole constitution') which granted the president the means to exercise his executive powers in a discretionary manner. Distortions in this system, resulting from the abuse of powers vested constitutionally in the executive presidency, have initiated debate in Uganda if this is the best system and whether the time has come to review and revise. Even when systems and regimes have not been changed substantially, violent conflicts have induced incremental changes in the institutions of governance, especially those dealing with law and order, judiciary and development of the social sectors. Strengthening of the institutions of national security, including military, police and intelligence agencies, has been a common feature in most of the African states. Some of the states like South Africa, and to some extent, Zimbabwe, increasingly display the characteristics of being national security states.

Conflicts have also brought violence to African societies in a big way. Many of the prominent African leaders fell to the bullets and blasts of assassins including former SecretaryGeneral of United Nations Organisation-Dag Hjalmar Agne Carl Hammarskjöld. Deaths of innocent African people in violent conflicts and terrorist attacks amount to thousands, women and children having been subjected to indescribable human rights abuses (UN, 1999). Such widespread violence and transmission of its gory images through television into the Africa living rooms and at dining tables are adding to the brutalisation of societies. Insurgencies and violent conflicts have also made Africa a prominent place of child-soldiers. African violent conflicts have significantly contributed to the deepening and aggravation of ethnic, communal and sectarian fault-lines. Also, identity-based polarisations have further fuelled political fragmentation and instability.

The impact of violent conflicts on economic growth and social development may be a matter of debate in Africa. Many experts argue that there are examples of violent conflict areas being quarantined to let economic activities go uninterrupted elsewhere. For instance, the dynamism of Djibouti's tourism and garment manufacturing sectors remaining unaffected by its violent conflict is often being referred to in this respect. Similarly, Kenyan economy has grown impressively while still coping with internal and external violent conflicts. But these examples are not very definitive as contrary examples of the countries like Angola, Burundi, the Central African Republic, Chad, DRC, 
Republic of Congo, Côte d'Ivoire, Djibouti, Eritrea, Ethiopia, Ghana, Guinea, GuineaBissau, Liberia, Niger, Nigeria, Rwanda, Senegal, Sierra Leone, South Africa, Sudan and Uganda, recording poor growth under the impact of violent conflicts as well.

There is however no denying the fact that violent conflicts escalate opportunity costs in the affected countries or even in other countries, especially for those that have trade relations with the affected states. In Mali, it has been publicly admitted by the leaders that the extremist insurgency is a major setback to Mali's growth. With the ending of insurgencies in some parts of Africa, prospects of growth have brightened. Leaders of all the regions in Africa have also repeatedly stressed that peaceful relations between them are necessary to maintain the momentum of growth and development. It is acknowledged in Africa that one of the greatest obstacles to the success of regional cooperation under Africa Union has been the violent conflicts in the Horn of Africa. As bi- and multilateral trade channels are being activated within the region, it is hoped that regional trade will grow to the advantage of all the member-countries. Violent conflicts and regional rivalries within the region are also obstructing the prospects of their mutual cooperation, which, if facilitated, can in turn help all other regions (Southern African Region, North African Region, Great Lakes region, West Africa and the Horn of Africa) fight their internal insurgencies better.

Violent conflicts in Africa have impinged adversely on the autonomy of the region and its countries. They have made the African states porous and vulnerable to external interventions and influences. Some of such influences have been both benign and destructive. The induction of Cold War in the region has been mutually reinforcing and is well documented (Trevor, 1999). Thus, we find that the consequences of violent conflicts in Africa have been diverse and damaging. These consequences have affected all the vital sectors of life in the region such as security, stability, political order, economic growth and development, social harmony and stability. Africa's people need to learn from these violent conflicts and commit themselves to resolving them in the interests of their own security and well-being.

\section{Are there any prospects towards African Conflicts?}

As opined by Meles Zenawi, a former prime minister of Ethiopia, violent conflicts are inherent in human nature as long as people are going to live in states and societies (Zenawi, 1999). Africa cannot be an exception in this respect. Almost all the causes of African violent conflicts listed in this paper, ranging from historical legacies to turbulent state- and nation-building processes and distorted developmental dynamics, continue to be relevant. Even when one set of violent conflicts is resolved, another set appears, maybe in a somewhat transformed or redefined form, to be dealt with.

The root causes of violent conflict in South Sudan as well as in Burundi remain unresolved and unmitigated despite efforts to put in place confidence-building measures. 
In Somalia, Al-Shabaab question remains unresolved and the spill-over of Somalia's internal identity crisis and dominance of army in politics generate instruments of violent conflicts like cross-border terrorism that continue to thrive, undercutting expressions of peaceful intent. Any repeat of a Garrissa, Kenyan-type cross-border terror attack, can trigger passions and political moves leading to an unmanageable situation. The rise of Boko Haram in Nigeria, Cameroon, Niger and Chad and Jihadi extremism in Mali may create conditions for such an attack.

Ethiopia and Somalia both have stakes in peace and stability so that their growth dynamics can go forward uninterrupted. Ethiopia's deepening engagement on territorial disputes with Somalia, hopefully, will keep it keen on having peace and understanding with Kenya. Ethiopia's new leadership has also laid greater emphasis on its perceived core interests in Ogaden where war drums are sounding louder than ever. Despite the imperative of keeping the East front peaceful and stable, Ethiopia seems less prepared to resolve the border issue and is worried about the possible firming up of strategic partnership between western and Arab world, impinging on its interests in the East African region. In such a situation, Ethiopia is making moves to disturb Somalia either directly, on the pretext of border and Ogaden district issues, or indirectly, by encouraging Cote Francaise des Somalis (now Republic of Djibouti) to keep Somalia engaged on its western front cannot be ruled out, howsoever remote it appears. It has been noted earlier that prior to colonialization, Somalia's strategic equations with the USSR and the USA, during the cold war era, was a major factor prompting Ethiopia to undertake the border offensive.

Inter-state violent conflicts within Africa, barring the Ethiopia-Somalia Ogaden, may be ruled out for any foreseeable future. There could be tensions on a number of other issues from the spill-over effects of internal conflicts to the sharing of resources (common rivers, territorial waters and extended maritime economic zone, trade and investment-related issues, human migration, etc.), but outright war looks nearly impossible. However, internal conflicts within African countries do not seem to be coming to an end in a foreseeable future. Africa's insurgencies (in Somalia, Mali, Cameroon, Libya, Niger and Chad) seem likely to persist. The African region is resilient in dealing with identity challenges and has also shown promise in coping with ideological insurgency, but the task of coordinating state actions in a divisive and federal polity with highly bureaucratised state institutions is not an easy one. Tensions within Africa on the ethnic question do not seem to be dying out anywhere. In Africa, a new polarisation between the secular and sectarian forces on the question of 'war crime trials' is gradually assuming threatening dimensions. In the West African and East African regions, Islamic extremism and sectarian clashes may experience a surge and in Mali the breakaway faction of the Tuaregs continues to adhere to the concept of 'people's war'.

Capabilities of the African states to effectively manage and/or resolve these internal conflicts would depend critically on two aspects: institutionalising democratic function- 
ing and ensuring a respectable pace of economic growth with distributive justice. Both these have so far proved to be formidable challenges in most of the African countries. For example, both South Sudan and DR Congo have so far failed to institutionalise the democratic upsurge witnessed in the first decade of the 21st century. It is to the credit of Burundi's elected civilian administration led by the Burundi Peoples' Party that it has completed its full term (only the third term in the entire history of Burundi so far), but the tensions among the principal governing institutions like the executive, army and judiciary seem considerably tumultuous. Reinforcing of democratic norms and economic growth will also strengthen African countries internally and will also improve the prospects of regional integration and cooperation through African Union.

\section{Conclusions and Recommendations}

Since the Balkanization and partition of Africa by colonialists, African countries have navigated a chequered military and civilian political trajectory whereby the economic growth and political development process have been interrupted time and again by competing political and military interests. Even when democratically elected civilian leaders are at the helm, key state institutions and policies appear to have been predominantly under the control of the military. Enabling the military's intervention in the affairs of government, civilian regimes in Africa have often rendered institutions as instruments for short-term solutions to deep-seated social and political problems and unrest. Long-term people-centred approaches promoting socio-economic development, equitable and just provision of human rights and conflict resolution processes to address genuine grievances of disaffected communities have generally been overlooked.

Successive military and civilian regimes have traditionally served the interests of the ruling class rather than the ruled. Corruption levels and the ineptitude of various democratically elected governments in Africa have over the years served to undermine the credibility of the democratic process itself. The military by virtue of its capacity to enforce a relatively greater semblance of law and order in the region was, for a long time, the most highly respected institution of the state. In Africa's recent history, however, there has been a dramatic reduction in the society's appetite for the militarization of politics and government. In a demonstration of this shift towards democratic consciousness across African society, the most recent elections held in African countries were the first occasions in the region's political history that an elected government, having completed a full mandated-year term uninterrupted by a military coup d'état, handed over power to a new government also elected by popular vote.

Regrettably, however, military dictatorships and civilian authoritarianism throughout Africa's history have undermined the development of robust state institutions upholding the social contract, the principle that government exists to serve the interests of society rather than those of the state and the ruling elite. The African state's unwillingness or 
inability to adequately provide public goods and services, justice and security, coupled with poor socioeconomic development, have extensively undermined its legitimacy, most evident in the zones of violence identified in this study. Pervasive insecurity, ungoverned spaces, parallel legal systems, the erosion of the social contract, the acute perception of relative deprivation and ethnic, religious and sectarian fragmentation are among some of the factors challenging the African state's writ, thereby sowing the seeds of political and extremist violence and perpetuating protracted conflict. The African state's own security-centred posturing continues to spur confrontations with various groups across the African countries in the region, exacerbating the perception of alienation and victimization in many African countries affected by violence. Data suggest that during the past decade, violence has become endemic across many parts of Africa. The region's own experience suggests that if the existing conditions persist, the region could face escalation of violence, widespread lawlessness and potential fragmentation. There is a dire need for a robust effort at good governance and people-centred policy reforms where socioeconomic development is accorded high priority to mitigate the perception of alienation and marginalization among various groups in African countries. Appropriate institutional responses by the African states are critical and necessary to transform the volatile environment. Given the diverse and broad spectrum of conflicts afflicting African region, it is important to analyse and address each conflict in its own context and plan for comprehensive African state stabilization and peace-building processes entailing both short- and long-term measures.

\section{References:}

1. Adebajo, A. (2010). The curse of Berlin: Africa after the cold war. New York: Columbia University Press.

2. Adedeji, A. (1999). Comprehending and mastering African conflicts: The search of sustainable peace and good government. London: Zed Books.

3. Adeyemo, F. O. (2000). Conflicts, wars and peace in Africa, 1960-2000. Lagos: Franc Soba Nig.

4. Africanews.com (2016). 26th AU summit opens in Addis Ababa. Africanews.com. Retrieved from www.africanews.com/2016/01/30/26th-au-summit-opens-in-addis-ababaregional-peace-and-security-tops-the-agenda/summit-opens-in-addis-ababa-region al-peace-and-security-tops-the-agenda/ (accessed 15 July, 2016).

5. Annan, K. (1998, April 13). The causes of conflict and the promotion of durable peace and sustainable development in Africa. Report of the Secretary-General to the Security Council, UN document no. S/1998/318.

6. Annan, K. (2001). War less likely between mature democracies. Lecture presented at Oxford University.

7. Eminue, O. (2004). Conflict resolution and management in Africa: a panorama of conceptual and theoretical issues. African Journal of International Affairs and Development, 9(1\&2), 23-67. 
8. Harvey, G. (1995). Issues in the analysis of ethnic conflict and democratization processes in Africa today. In H. Glickman (Ed.), Ethnic conflict and democratization in Africa (pp. 1-31). Atlanta: African Studies Association.

9. Global Peace Index (GPI) (2014). Measuring peace and assessing country risk. Sydney: Institute for Economics and Peace.

10. Laitin, D. D. (2007). Nations, states, and violence. Oxford and New York: Oxford University Press.

11. Obi, C. (2012). Conflict and peace in West Africa. Uppsala, Sweden: The Nordic Africa Institute.

12. Otite, O. (1999). On conflicts, their resolutions, transition and management. In O. Otite and I.O. Albert (Eds.), Community conflicts in Nigeria: management, resolution and transformation (pp. 27-56). Ibadan: Spectrum Books.

13. Trevor, G. (1999). Conclusion and recommendations on managing African conflicts in their political, economic and social dimensions. In. A. Adedeji (Ed.), Comprehending and mastering African conflicts: the search for sustainable peace and good governance synopsis (pp. 45-79). London: Zed Books.

14. United Nations. (1999). The causes of conflict and the promotion of durable peace and sustainable development in Africa. Report of the UN Secretary-General, New York: United Nations.

15. Viggo, J. P. (2002). The transformation of United Nations peace operations in the 1990s: adding globalization to the conventional 'end of the cold war explanation. Cooperation and Conflict, 37(3), 267-282.

16. Zartman, W. (2013). The diplomacy of African boundaries. In J. W. Harbeson and D. Rothchild (Eds.), Africa in world politics: engaging a changing global order (5th Ed.) (p. 173). Boulder: Westview Press.

17. Zenawi, M. (1999). Opening statement to the all-Africa conference on African principles of conflict resolution and reconciliation, Addis Ababa, November.

18. Zounmenou, D., \& Okeke, J. M. (2012). The challenge of ending political violence in Guinea-Bissau. Pretoria, South Africa: Institute for Security Studies (ISS). 